\title{
Interface between Maternal Antibodies and Natural Challenge for Bovine Viral Diarrhea Virus (BVDV) in Holstein Heifers
}

\author{
Camila Costa Baccili', Natália Meirelles Sobreira ', Bruno Toledo Silva', \\ Edviges Maristela Pituco ${ }^{2}$ \& Viviani Gomes'
}

\begin{abstract}
Background: Newborn calves are agammaglobulinemic, immunosuppressed and immunologically immature at birth. The passive immune transfer is fundamental to protect calves against pathogens. The decay of maternal antibodies precedes the immune maturation at puberty enhancing the susceptibility of calves to infections caused by BVDV. Then, the objective of this research was to evaluate the interface between passive and active immunity for Bovine Viral Diarrhea Virus (BVDV) in Holstein dairy heifers in the first 13 months of age to detect susceptibility periods and establish prophylactic measures on prevention of Bovine Viral Diarrhea.

Materials, Methods \& Results: Sera were analyzed from 585 heifers by serum neutralization (SN) and enzyme linked immunosorbent assay (ELISA) for the $\mathrm{p} 80$ protein of BVDV. Heifers were categorized according to their age by the month of life. Heifers were seropositive $(100 \%)$ from $1^{\text {st }}$ to $13^{\text {th }}$. Median of neutralizing antibodies $(\mathrm{Ab})$ titers obtained from $1^{\text {st }}$ up to $13^{\text {th }}$ month were $316.2 ; 125.9 ; 63.1 ; 50.1 ; 50.1 ; 39.8 ; 63.1 ; 63.1 ; 39.8 ; 79.4,100.0 ; 74.4$; and 79.4 , respectively. The neutralizing $\mathrm{Ab}$ titers obtained in $1^{\text {st }}$ month were different of the values observed from $2^{\text {nd }}$ until $13^{\text {th }}(P<0.001)$, furthermore the $\mathrm{Ab}$ titers from $2^{\text {nd }}$ month was statistical different of $4^{\text {th }}(P=0.01)$ and $6^{\text {th }}(P=0.05)$. The frequencies $(\%)$ of positive heifers for p80 from $1^{\text {st }}$ up to $13^{\text {th }}$ were $24.7 ; 18.2 ; 10.4 ; 11.8 ; 73.3 ; 73.8 ; 72.4 ; 58.1 ; 45.9 ; 48.4 ; 46.2 ; 43.8$ and 61.5 , respectively. The correlation observed for neutralizing Ab titers and age was negative and weak $(\rho=-0.299 ; P<0.001)$. On the other hand, the correlation between positive heifers for $\mathrm{p} 80$ and age was positive and moderate $(\rho=0.319 ; P<0.001)$.

Discussion: The newborn calves had higher titers of neutralizing antibodies than other age groups and some calves were seropositive for the $\mathrm{p} 80$ protein. This profile points to the transfer of maternal antibodies produced by vaccination and/or natural exposure to BVDV. The exposure of the cows to the inactivated and live virus stimulates the production of neutralizing antibodies to the structural proteins of the virus, particularly the glycoprotein E2, detected by the serum neutralization test. The titers of serum neutralizing antibodies and the frequencies of seropositive for p 80 protein decreased gradually from the first to the $4-6^{\text {th }}$ month of life due to the metabolization of maternal immunoglobulins acquired by ingestion of colostrum. Frequencies of seropositive animals for protein p 80 increased from the fifth month of life, which is the same moment that was observed declined of neutralizing maternal antibody titers. The phase of higher frequency of p80 positive animals coincides with greater rates of Babesiosis and Anaplasmosis. This history could justify the importance of the BVDV immunodepression as a risk factor for concomitant diseases. In general, the neutralizing antibody titers increased after the peaks of positive reactions to the $\mathrm{p} 80$ protein, but this moment coincides with the primo-vaccination in calves. Therefore, it is not possible to state the origin of these antibodies. Correlations between ages and serologic tests are consistent with previous data reporting the decrease in antibody titers and increase of seropositive animals for p 80 protein, from the first month of life to puberty. In conclusion, maternal neutralizing Ab titers had gradual decreased whereas the frequency of positive heifers for $\mathrm{p} 80$ had increased values. The inversion observed between the maternal antibody titers and the increase in antibody for p80 indicates the moment of greatest risk for natural infections caused by BVDV.
\end{abstract}

Keywords: maternal antibodies, Bovine Diarrhea Virus (BVD), serum neutralization test, p80 protein. 


\section{INTRODUCTION}

Newborn calves are agammaglobulinemic, immunosuppressed and immunologically immature at birth. The development of immune system occurs slowly and gradually until it reaches a status similar to adults at six months after birth. Young calves depend on passive immunity transferred from cows as the primary basis for protection against diseases [5].

Maternal Ab titers for BVDV decline and its length depend on the amount ingested, absorbed and the decay rate [9]. Postnatal BVDV infections in calves with low levels of maternal antibodies $(\leq 16)$ result in acute and intense disease characterized by hyperthermia, leukopenia, thrombocytopenia and diarrhea. In contrast, animals fed with colostrum derived from vaccinated cows, developed mild clinical signs or did not express the disease after experimental infection [1].

Passive immunity is a double-edged sword for young calves: protection from diseases on one side, and interference with a calf's ability to develop immunity to vaccine antigens on the other [3]. While passive immunity provides protection against disease it could blocks the production of serum antibodies when immunogens are administered to calves with maternally derived antibodies. However, others studies have shown that some immunogens can induce immunological memory that is not susceptible to maternal antibody regulation [7].

The decay of maternal antibodies precedes the immune maturation at puberty enhancing the susceptibility of calves to infections caused by BVDV. Then, the objective of this research was to evaluate the interface between passive and active immunity for Bovine Viral Diarrhea Virus (BVDV) in Holstein dairy heifers in the first 13 months of age to detect susceptibility periods and establish prophylactic measures on prevention of Bovine Viral Diarrhea.

\section{MATERIALS AND METHODS}

\section{Animals and sample collection}

The study was performed with 585 Holstein heifers on a commercial dairy herd in a high production system with average milk production of $66,000 \mathrm{~L} /$ day, located in the state of São Paulo, Brazil, between coordinates $22^{\circ} 10^{\prime}$ to $22^{\circ} 30^{\prime}$ south latitude and $47^{\circ} 15^{\prime}$, to $47^{\circ} 30^{\prime}$ west longitude.
The herd was composed of approximately 3,700 Holstein cows, with 1,750 producing around $38.5 \mathrm{~L}$ of milk production per day and 95 calves from 1 up to 70 days of life. Right after birth, the animals are kept singly in elevated calf hutches $\left(1 \mathrm{~m}^{2}\right)$ in a calf barn with an area of $112.5 \mathrm{~m}^{2}$ and a height of $4.5 \mathrm{~m}$ $\left(1.18\right.$ animal unit $\left./ \mathrm{m}^{2}\right)$. After this period, the animals are housed into confinement paddocks where they remain until the next delivery date, being transferred then to the maternity barn. After delivery, lactating cows are kept in a barn with cross ventilation system and when they reach the dry period they are reallocated to the free stall barn.

The births were assisted and calves were separated immediately after birth and transferred to individual pens. Four liters of frozen colostrum of the first milking were administered into two feedings during the first $12 \mathrm{~h}$ after birth. The frozen colostrum used was from multiparous donors, whose immune quality was estimated by colostrometer $(\geq 50 \mathrm{~g} / \mathrm{L}$ of immunoglobulin). The thawing was performed in a water bath $\left(45-50^{\circ} \mathrm{C}\right)$ until the colostrum reached $37^{\circ} \mathrm{C}$. Then, the calves were fed with six liters of milk replacer $\left(\text { Lacthor }^{\circledR}\right)^{1}$ per day.

The vaccination protocol from the farm starts with calves on 120 days of age with booster at 150 days, followed by semi-annual revaccination held in April and October. The commercial vaccine used was composed by inactivated strains of BVDV type 1 (5960) and type 2 (53637); live/thermosensitive BoHV-1 (Cooper) and BPIV-3 (RLB 103); live/ attenuated BRSV (375) and Leptospira spp., associated with Quil A, cholesterol and Amphigen as adjuvants.

Blood samples were collected by puncture of the external jugular vein, using vacuum blood tubes without anticoagulant $(20 \mathrm{~mL})$ to carry out the serological tests. In the laboratory, samples were centrifuged at $800 \times \mathrm{g}$ for $15 \mathrm{~min}$ and the serum obtained was transferred to micro tubes and stored at $-80^{\circ} \mathrm{C}$.

\section{Serological test}

The serum neutralization test ( $\mathrm{SN})$ was accomplished using 96-well polystyrene plates [14]. The serum was serially diluted in $\log _{2}$ steps from 1:10 (BVDV-NADL) using minimal essential medium (MEM) containing $1 \%$ to $2 \%$ of antibiotics. The diluted samples were added in duplicate to wells in the plate. Then, it was added $50 \mu \mathrm{L}$ con- 
taining $\mathrm{TCID}_{50} / 100 \mu \mathrm{L}$ (50\% tissue culture infective doses) from BVDV. After, plates were incubated for $1 \mathrm{~h}$ for $\mathrm{BVDV}$ at $37^{\circ} \mathrm{C}$ in incubator with $5 \%$ $\mathrm{CO}_{2}$. Subsequently, Madin-Darby bovine kidney (MDBK) cell suspension was added to each well. Plates were once more incubated at $37^{\circ} \mathrm{C}$ with $5 \%$ $\mathrm{CO}_{2}$ for 4 to 5 days.

Infectivity was measured based on the cytopathic effect (CPE) visible in the cell monolayer on the plates by using an inverted microscope. Antibody titer was expressed as the highest dilution of the serum that completely inhibited the infectivity and therefore the CPE in both the wells of each dilution.

Antibodies against $\mathrm{p} 80$ protein of BVDV were detected by enzyme linked immunosorbent assay (ELISA) using a commercial kit (SERELISA ${ }^{\circledR}$ BVD p80 Ab Mono blocking kit, Synbiotic) $)^{2}$. The procedures and interpretation of the reactions were performed according to the manufacturer's recommendations.

\section{Statistical analysis}

Statistical analysis was performed using the SPSS 20.0 program $^{3}$. The antibody titers were converted to base-2 logarithm, however presented non-normal distribution by Shapiro-Wilk and Kolmogorov-Smirnov tests. The medians of the titers were calculated and differences between moments were obtained using the Kruskal-Wallis test. Finally, the values were converted in antilog by the expression $=2^{\mathrm{a}}$, where "a" is the median of antibody titers in $\log _{2}$.

The frequencies of positive and negative animals for BVDV p80 protein were calculated. The chi-square test was used to detect differences in the frequencies $(\%)$ between times.

Correlations between age groups and serological tests were calculated using Spearman correlation test $(P<0.05)$. The results were interpreted according to the classification of statistical authors [6], in which the closer to 1 (regardless of sign) is the Spearman correlation coefficient $(\rho)$, the greater will be the degree of statistical dependence. This dependence may be weaker when $\rho=0.1$ to 0.3 ; moderate with $\rho=0.4$ to 0.6 and strong when $\rho=0.7$ to 1.0 .

\section{RESULTS}

All the animals evaluated $(n=585)$, from the $1^{\text {st }}$ to the $13^{\text {th }}$ month of life, were seropositive (100\%) for BVDV by SN test.
The medians for the antibody titers obtained in the first thirteen months of life were, respectively, $316.2 ; 125.9 ; 63.1 ; 50.1 ; 50.1 ; 39.8 ; 63.1 ; 63.1 ; 39.8$; $79.4,100.0 ; 74.4$; and 79.4. Gradual decrease was noted in the value from the first to sixth month of life. Differences in the Ab titers presented by newborn calves could be detected when compared to other age groups. Calves with two months of age had higher $\mathrm{Ab}$ titers than those with four and six months of age (Table 1).

Table 1. Median of specific antibody titers for BVDV in serum of Holstein heifers, from 1 st up to $13^{\text {th }}$ month of life.

\begin{tabular}{cccc}
\hline Age (months) & $\log _{2}$ & Antilog & Range \\
\hline 1 & $8.3^{\mathrm{b}-\mathrm{m}}$ & 316.2 & $10-631$ \\
2 & $7.3^{\text {a.d.f }}$ & 125.9 & $10-631$ \\
3 & $6.3^{\mathrm{a}}$ & 63.1 & $10-631$ \\
4 & $5.3^{\mathrm{a} . \mathrm{b}}$ & 50.1 & $10-631$ \\
5 & $6.3^{\mathrm{a}}$ & 50.1 & $10-631$ \\
6 & $5.3^{\mathrm{a} . \mathrm{b}}$ & 39.8 & $10-631$ \\
7 & $6.3^{\mathrm{a}}$ & 63.1 & $10-631$ \\
8 & $6.3^{\mathrm{a}}$ & 63.1 & $10-631$ \\
9 & $5.3^{\mathrm{a}}$ & 39.8 & $10-631$ \\
10 & $6.3^{\mathrm{a}}$ & 79.4 & $10-631$ \\
11 & $6.3^{\mathrm{a}}$ & 100.0 & $10-631$ \\
12 & $6.3^{\mathrm{a}}$ & 79.4 & $10-316$ \\
13 & $6.3^{\mathrm{a}}$ & 79.4 & $10-631$ \\
\hline
\end{tabular}

Lowercase letters in the same column show differences between the ages obtained by Kruskal Wallis test with (a) different values from $1^{\text {st }}$; (b) $2^{\text {nd }} ;$ (c) $3^{\text {rd }} ;$ (d) $4^{\text {th }} ;$ (e) $5^{\text {th }} ;$ (f) $6^{\text {th }} ;$ (g) $7^{\text {th }} ;$ (h) $8^{\text {th }}$; (i) $9^{\text {th }}$; (j) $10^{\text {th }}$; (k) $11^{\text {th }}$; (l) $12^{\text {th }}$; (m) $13^{\text {th }}$ months of life when $P<0.05$.

The proportions of positive heifers for $\mathrm{p} 80$ were $24.7 ; 18.2 ; 10.4 ; 11.8 ; 73.3 ; 73.8 ; 72.4 ; 58.1$; $45.9 ; 48.4 ; 46.2 ; 43.8$ and 61.5 , respectively from the first to $13^{\text {th }}$ months of age (Table 2). A gradual decrease in the frequencies could be observed from the first to fourth month of life. The peak of positive reactions was noted between 5 and 7 months and then the values decreased and become relatively constant. The differences in the frequencies between the months are shown in Table 3.

The correlation observed between Ab titers and the different age groups was negative and weak $\rho=-0.299(P<0.001)$. In contrast, the correlation obtained between the positives animals for $\mathrm{p} 80$ protein and ages was moderate positive $\rho=0.319$ $(P<0.001)$. 
Table 2. Absolut values and frequencies for $\mathrm{p} 80$ protein in Holstein heifers obtained by direct immunoenzymatic test.

\begin{tabular}{cccccc}
\hline \multicolumn{5}{c}{$\begin{array}{c}\text { Ege } \\
\text { (months) }\end{array}$} & \multicolumn{3}{c}{$\begin{array}{c}\text { Absolute } \\
\text { values }\end{array}$} & Frequencies (\%) & & $\begin{array}{c}\text { Absolute } \\
\text { values }\end{array}$ & Frequencies (\%) \\
\cline { 2 - 4 } & 22 & 24.7 & 67 & 75.3 \\
2 & 14 & 18.2 & 63 & 81.8 \\
3 & 7 & 10.4 & 60 & 89.6 \\
4 & 6 & 11.8 & 45 & 88.2 \\
5 & 44 & 73.3 & 16 & 26.7 \\
6 & 31 & 73.8 & 11 & 26.2 \\
7 & 42 & 72.4 & 16 & 27.6 \\
8 & 18 & 58.1 & 13 & 41.9 \\
9 & 17 & 45.9 & 20 & 54.1 \\
10 & 15 & 48.4 & 16 & 51.6 \\
11 & 6 & 46.2 & 7 & 53.8 \\
12 & 7 & 43.8 & 9 & 56.3 \\
13 & 8 & 61.5 & 5 & 38.5 \\
\hline
\end{tabular}

Table 3. Significant differences obtained between months to positive and negative frequencies for BVDV p80 protein in Holstein heifers.

\begin{tabular}{cccccccc}
\hline Age (months) & 1 & 2 & 3 & 4 & 5 & 6 & 7 \\
\hline 3 & 0.0479 & & & & & & \\
5 & 0.001 & 0.001 & 0.0001 & 0.0001 & & & \\
6 & 0.001 & 0.001 & 0.0001 & 0.0001 & & & \\
7 & 0.001 & 0.001 & 0.0001 & 0.0001 & & 0.0214 & \\
8 & & 0.001 & 0.0001 & 0.0001 & & 0.0478 & \\
9 & 0.0327 & 0.0038 & 0.0002 & 0.0008 & 0.0126 & 0.0214 & 0.0175 \\
10 & 0.0256 & 0.003 & 0.0001 & 0.0006 & 0.0331 & & \\
11 & & & 0.0066 & 0.0148 & & & \\
12 & & 0.0258 & 0.002 & 0.0056 & & & \\
13 & 0.0166 & 0.0026 & 0.0001 & 0.0005 & & & \\
\hline
\end{tabular}

Significances between group ages to frequencies (\%) obtained by Chi-square test when $P<0.05$.

\section{DISCUSSION}

This research evaluated the interface between passive and active immunity to BVDV of Holstein heifers $(n=585)$ raised in confinement dairy production system from the first to the $13^{\text {th }}$ month of life.

The infection due to natural exposure to the virus was investigated by detection of specific anti- bodies against the nonstructural protein p80 (NS3). This polypeptide is produced by cytopathic BVDV during the viral replication process and therefore stimulates the production of antibodies only in naturally infected animals or vaccinated with modified live virus $[10,11]$. The dairy farm selected for this research never used live vaccines for BVDV due to prohibitive legislation in our country. Thus, the pres- 
ence of seropositive animals for p80 indicates the virus circulation within the herd.

The newborn calves had higher titers of neutralizing antibodies than other age groups and also some calves were seropositive for the $\mathrm{p} 80$ protein. This profile points to the transfer of maternal antibodies produced by vaccination and/or natural exposure to BVDV. The exposure of the cows to the inactivated and live virus stimulates the production of neutralizing antibodies to the structural proteins of the virus, particularly the glycoprotein E2, detected by the serum neutralization test [13].

The titers of serum neutralizing antibodies and the frequencies of seropositive for $\mathrm{p} 80$ protein decreased gradually from the first to the 4-6th month of life due to the metabolization of maternal immunoglobulins acquired by ingestion of colostrum. Maternal antibodies was detected in the circulation of calves up to six months of life [12], but the persistence of these immunoglobulins may be higher depending on the quality of ingested colostrum [9].

Frequencies of seropositive animals for protein p80 increased from the fifth month of life, which is the same moment that was observed declined of neutralizing maternal antibody titers. At this moment, the median observed for neutralizing antibody titers was 50. Researchers demonstrated that calves with antibody titers above 16 developed mild disease after experimental infection with BVDV [1]. The presence of others management-related risk factors could justify the high frequency of positive animals for BVDV presenting higher antibody titers than those protectors.

The calves are kept in individual pens from birth up to 70 days of life and then are re-allocated to barns in groups around 20 animals. From four months old, all the animals are transferred to an area of collective confinement, where they remain until the first artificial insemination. Thus, the insertion and greater contact between animals in this last stage of heifers raising may have been primordial in the spread of BVDV in this age group. It is also worth noting that stress resulting from the re-socialization and feed management contributes for the BVDV epidemiology, as the decrease of maternal antibodies does.

The phase of higher frequency of $\mathrm{p} 80$ positive animals coincides with greater rates of Babesiosis and Anaplasmosis. This history could justify the importance of the BVDV immunodepression as a risk factor for concomitant diseases.

BVDV infects neutrophils, monocytes and dendritic cells [2]. Neutrophils from infected animals have been reported to reduce phagocytosis and microbicidal activity, which persists during the first two weeks post-infection [15]. The lymphocytes tropism by the virus results in depletion of lymphoid organs and immunodepression [8]. This imbalance in the innate immune response, as well as depletion of the lymphocytes subpopulations, promotes and exacerbates any concomitant disease to BVDV infection [4].

In general, the neutralizing antibody titers increased after the peaks of positive reactions to the p80 protein, but this moment coincides with the primovaccination in calves. Therefore, it is not possible to state the origin of these antibodies.

Correlations between ages and serologic tests are consistent with previous data reporting the decrease in antibody titers and increase of seropositive animals for $\mathrm{p} 80$ protein, from the first month of life to puberty.

\section{CONCLUSION}

In conclusion, maternal neutralizing $\mathrm{Ab}$ titers had gradual decreased whereas the frequency of positive heifers for $\mathrm{p} 80$ had increased values. The inversion observed between the maternal antibody titers and the increase in antibody for p80 indicates the moment of greatest risk for natural infections caused by BVDV.

\section{MANUFACTURERS}

${ }^{1}$ Tortuga Cia. Zootécnica Agrária - Nutrição. Mairinque, SP, Brazil. ${ }^{2}$ Delpharm biotech. Lyon, France.

${ }^{3}$ IBM International Business Machines Corporation. Armonk, NY, USA.

Funding. This research was supported by grant from São Paulo Research Foundation (Project Number 2010/15865-9). The authors would like to thank the Zoetis (Brazil) for providing the test kits (SERELISA ${ }^{\circledR}$ BVD p80 Ab Mono blocking kit, Synbiotic).

Ethical approval. All applicable international, national, and/ or institutional guidelines for the care and use of animals were followed.

Declaration of interest. The authors declare that there is no conflict of interest that could be perceived as prejudicing the impartiality of the research reported. 


\section{REFERENCES}

1 Bolin S.R. \& Ridipath J.F. 1995. Assessment of protection from systemic infection or disease afforded by low to intermediate titers of passively acquired neutralizing antibody against bovine viral diarrhea virus in calves. American Journal Veterinary Research. 56(6): 755-759.

2 Chase C.C.L., Elmowalid G. \& Yousif A.A.A. 2004. The immune response to bovine viral diarrhea virus: a constantly changing picture. Veterinary Clinics of North America: Food Animal Practice. 20(1): 95-114.

3 Chase C.C.L., Hurley D.J. \& Reber A.J. 2008. Neonatal Immune Development in the Calf and Its Impact on Vaccine Response. Veterinary Clinics of North America: Food Animal Practice. 24(1): 87-104.

4 Chase C.C.L., Thakur N., Darweesh M., Morarie-Kane S.E. \& Rajput M.K. 2015. Immune response to bovine viral diarrhea virus-looking at newly defined targets. Animal Health Research Reviews. 16(1): 4-14.

5 Cortese V.S. 2009. Neonatal Immunology. Veterinary Clinics of North America: Food Animal Practice. 25(1): 221-227.

6 Dancey C.P. \& Reidy J. 2005. Análise de correlação: o r de Pearson. In: Estatística sem matemática para psicologia. Porto Alegre: Artmed, pp.178-216.

7 Ellis J., West K., Cortese V., Konoby C. \& Weigel D. 2001. Effect of maternal antibodies on induction and persistence of vaccine-induced immune responses against bovine viral diarrhea virus type II in young calves. Journal American Veterinary Medical Association. 219(3): 351-356.

8 Falkenberg S.M., Johnson C., Bauermann F.V., McGill J., Palmer M.V., Sacco R.E. \& Ridpath J.F. 2014. Changes observed in the thymus and lymph nodes 14 days after exposure to BVDV field strains of enhanced or typical virulence in neonatal calves. Veterinary Immunology Immunopathology. 160(1-2): 70-80.

9 Fulton R.W., Briggs R.E., Payton M.E., Confer A.W., Saliki J.T., Ridpath J.F., Burge L.J. \& Duff G.C. 2004. Maternally derived humoral immunity to bovine viral diarrhea virus (BVDV) 1a, BVDV1b, BVDV2, bovine herpesvirus-1, parainfluenza-3 virus bovine respiratory syncytial virus, Mannheimia haemolytica and Pasteurella multocida in beef calves, antibody decline by half-life studies and effect on response to vaccination. Vaccine. 22(5-6): 643-649.

10 González A.M. Arnaiz I. Yus E. Eiras C. Sanjuán M. \& Diéguez F.J. 2014. Evaluation of long-term antibody responses to two inactivated Bovine Viral Diarrhea Virus (BVDV) vacines. The Veterinary Journal. 199(3): 424-428.

11 Graham D.A., German A. Mawhinney K. \& Goodall E.A. 2003. Antibody responses of naive cattle to two inactivated bovine viral diarrhoea virus vaccines, measured by indirect and blocking ELISAs and virus neutralization. Veterinary Record. 152(26): 795-800.

12 Menanteau-Horta A.M., Ames T.R. \& Johnson D.W. 1985. Effect of maternal antibody upon vaccination with infectious bovine rhinotracheitis and bovine virus diarrhea vaccines. Canadian Journal Compendium Medical. 49(1): 10-14.

13 Nobiron I., Thompson I., Brownlie J. \& Collins M.E. 2003. DNA vaccination against bovine viral diarrhea vírus induces humoral and cellular responses in cattle with evidence for protection against viral challenge. Vaccine. 21(1718): 2082-2092.

14 OIE-World Organization for Animal Health. 2015. Bovine viral diarrhea. In: Manual of Diagnostic Tests and Vaccines for Terrestrial Animals. http://www.oie.int/fileadmin/Home/eng/Health_standards/tahm/2.04.08_BVD.pdf. [Accessed February 2016].

15 Roth J.A., Kaeberle M.L. \& Griffith R.W. 1981. Effects of bovine viral diarrhea virus infection on bovine polymorphonuclear leukocyte function. American Journal of Veterinary Research. 42(2): 244-250.

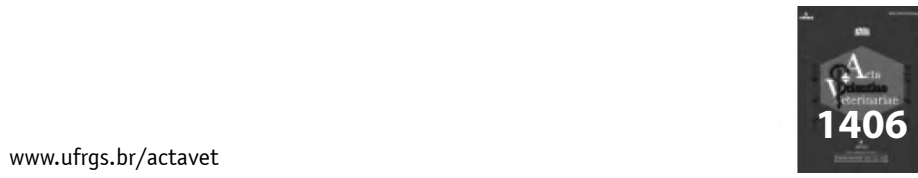

